\title{
полИТОЛОГИЯ
}

DOI: $10.17805 /$ trudy.2015.3.10

\section{РОССИЯ: ОТ ВЛАСТВОВАНИЯ - К ПОЛИТИЧЕСКОЙ СИСТЕМЕ}

\author{
В. И. Буренко \\ (Московский гуманитарный университет)
}

\begin{abstract}
Аннотация: В статье анализируется проблема становления политической системы в России, которая началась с формирования балансов и противовесов в соотношении частных, групповых и государственных интересов.
\end{abstract}

Ключевые слова: политическая система, политика, Россия, история политики.

\section{RUSSIA: FROM DOMINATION TO A POLITICAL SYSTEM}

\author{
V. I. Burenko \\ (Moscow University for the Humanities)
}

Abstract: The article analyzes Russia's emerging political system, which began with setting checks and balances in the correlation between private, collective and state interests

Keywords: political system, politics, Russia, history of politics.

Современный российский словарь насыщен употреблением понятия «политика», но реальную политику в обществе осуществлять все труднее. Политикой стало заниматься опасно. Оппозиционеров и политических журналистов убивают. Активных граждан, возмущенных фальсификациями на выборах таскают по судам. Журналистов, фиксирующих на камеры вбросы пачек бюллетеней, избивают. Правозащитные организации причисляют к организациям «иностранным агентам».

Современное понимание политики не сводит ее только к деятельности государства. Такое (этатистское от франц. état - 'государство') понимание политики господствовало до конца XIX века и было обусловлено тем, что государство являлось в значительной мере единственным институтом, осуществляющим политику, то есть принимающим решения и решающим проблемы, стоящие перед сообществом. Кратологическая (греч. kratos - 'власть', греч. logos - 'учение') трактовка политики представляет ее как сферу отношений, где взаимодействуют, конкурируют, противо- 
борствуют индивиды и общественные группы по вопросам, связанным с борьбой за государственную власть, ее использование и удержание, а также влияние на власть с целью реализации своих интересов.

Политика как отношение и вид деятельности осуществляет ряд важных общественно-значимых функций.

В политическом процессе осуществляется согласование интересов различных социальных групп, а также интересов этих групп и общезначимых интересов. Не случайно со времен Древнего мира политика характеризуется как «согласительное искусство». Посредством политики осуществляется формирование общенародного и общегосударственного интереса. Через политику как деятельность государства осуществляется управление общественными процессами. Здесь, как правило, задействована административно-бюрократическая сторона деятельности государства, связанная с функционированием экономики, социальной и культурной сфер общества. Через политику как деятельность государства осуществляется властвование, то есть навязывание обществу воли (интересов) тех или иных групп, овладевших государством как важнейшим ресурсом. Посредством политики как сферы влияния на власть, борьбы за власть и ее использование осуществляется политическая социализация граждан, рекрутирование политических лидеров и государственных деятелей.

Политика порождается альтернативностью, несогласием, конфликтностью интересов различных социальных субъектов. Существенным аспектом содержания политики является поиск выхода из альтернативной или конфликтной ситуации посредством достижения согласия. В этом смысле политика характеризуется в качестве процесса, обладающего конфликтно-консенсусной природой. Когда согласие достигнуто, (преодолена альтернативность), политика уходит. Приходит время государственного (административного) управления. Чем дольше затягивается процесс достижения консенсуса, тем более затруднений для управления, нарастает конфликтность, дестабилизация в общественном развитии. Это одна из причин монополизации процесса принятия решений главами государств, правительств и т. п.

Но если решения по всем значимым вопроса конфликтного характера монополизированы - это свидетельство отступления или уничтожения политики. В таком случае имеем дело с властвованием, а не с политикой. Монопольно принятые решения, необходимо, как правило, подкреплять силой, угрозами, манипуляциями в отношении тех социальных групп, интересы которых ущемлены или которые имели другие подходы к решению той или иной проблемы. Различение «властного» И «политического» четко проводит Э. Фегелин, когда исследует причины усиления артикуляции групповых интересов, связанные с усложнением социальных струк- 
тур позднего Средневековья и в этой связи выделяет переходный период от «просто королевской власти к политическому королевству» (Фегелин, 1997: 441), когда короли были вынуждены идти на уступки представителям знати и городов, учитывать их интересы при принятии решений.

Период с XV - до начала XVI в. представляет интерес тем, что именно тогда в Московском государстве начинает также формироваться политика как процесс поиска балансов и противовесов в соотношении частных, групповых и государственных интересов. Московское государство на протяжении примерно ста лет развивалось через сложный процесс согласования интересов основных субъектов того времени. «Боярство и самодержавие являлись неразрывно связанными силами. Приходилось думать о компромиссе...» (Валишевский, 1989: 41). Кроме этих двух сил «по крайней мере до половины XVI века духовная власть представителей церкви и особенно митрополита служила благодетельным противовесом всемогуществу государства» (там же: 264). Церковь выступала духовным противовесом государству, осуждая неправедные действия князей. Хотя эта позиция церкви была в московском государстве довольно условна. Так, уже Василий III (годы правления 1505-1533) назначал митрополитов без учета мнения церковного собора (Сергеев, 1997: 405). Все же некоторые митрополиты отстаивали самостоятельность церкви и ее право давать оценку действиям государей. К примеру, Н. И. Костомаров так описывает процедуру утверждения в 1566 г. митрополитом соловецкого игумена Филиппа. Филипп заявляет Ивану Грозному: «Не смотрите на то, что бояре молчат; они связаны житейскими выгодами, а нас Господь для того и отрешил от мира, чтоб мы служили истине, хотя бы и души наши пришлось положить за паству.... Я повинуюсь твоей воле, но оставь опричнину, иначе мне быть в митрополитах невозможно. Твое дело не богоугодное. ...На такое дело нет и не будет тебе нашего благословения» (Костомаров, 1991: 300).

Таким образом, в Московском государстве до середины XVI в. формировалась система взаимодействия интересов, близкая к европейской модели: царская власть, аристократия, церковь, права и привилегии вольных городов Новгорода и Пскова. В столкновениях этих интересов на российской почве складывалась и начинала функционировать политика как система поиска компромиссов и согласования частных, корпоративных и общих интересов.

Но в этот же период в русле концепции вотчинного властвования, доминирующей в среде политического класса того времени, начинают артикулироваться две модели правления, каждая из которых в разной степени вела к сужению сферы политики.

С одной стороны, образование национального великорусского госу- 
дарства отразилось в боярском сознании «теорией аристократического правления», согласно которой, как отмечал русский историк С. Ф. Платонов, родословная московская знать, выступала особым правящим классом, который вместе с государем стоял высоко над всем московским обществом, руководя его судьбами (Платонов, 1995).

С другой стороны, политические помыслы московских царей этого периода и особенно Ивана IV сводились «к одной идее, к мысли о самодержавной власти» (Ключевский, 1993a: 458).

В борьбе этих двух моделей правления многие историки видят истоки опричнины. Как отмечал В. О. Ключевский, цель опричнины «состояла в том, чтобы истребить крамолу, гнездившуюся в Русской земле, преимущественно в боярской среде» (там же). Анализируя результаты опричнины, С. Ф. Платонов подчеркивал, что «она сокрушила землевладение знати, ... политическое значение класса было бесповоротно уничтожено, и в этом заключался успех политики Грозного» (Платновой, 1995: 87). Близкую характеристику опричнине дает и польский историк К. Валишевский: «опричнина вместе с системой местничества успели стереть все привилегии и преимущества, основанные на исторических правах» (Валишевский, 1993: 10).

В ожесточенной кровавой борьбе ${ }^{1}$, продолжавшейся с 30-х годов XV и до середины второй половины XVI в. линия европейского политического развития прерывается. Вместе с опричниной ликвидируются основы нарождающейся политики. Политические механизмы и институты поиска компромиссов в этой борьбе создать не удалось. Отношения с социальными силами отныне выстраиваются на основе принципов властвования, а не политики. Воля государя в системе принятия решений приобретает неограниченный характер, несмотря на то, что при Иване Грозном собирались некоторые «представительные органы», которые, однако, никак не представляли и не защищали интересы тех или иных социальных слоев того времени. Так, характеризуя времена Ивана Грозного, М. М. Ковалевский писал: «Во всех этих соборах, собраниях и комиссиях не было ни разу ни одного выборного от населения народного представителя; это были чисто правительственные совещания, не желавшие считаться с народными интересами и прибегать к народному уму» (Ковалевский, 1997: 239).

Каковы причины столь неудачного становления политики как системы согласования интересов. Исследования отмечают позднее вступление России на путь исторического развития, специфические природные условия и потому, формирование особого, мобилизационного типа развития и др. К примеру, уже в то время оказали свое влияние геополитические факторы. Так, неопределенность территории позволяла населению свободно мигрировать. Историки отмечают, что революция сверху, которую произвел Иван Грозный, удалась только потому, что тягловое 
население боярских земельных владений ударилось в казачество, вырвалось из тягла и ушло в «Дикое поле». И это привело к тому, что «боярское крупное землевладение пало, родовая аристократия обеднела и не могла противостоять монархической власти, как противостояла феодальная аристократия Запада» (Алексеев, 1998: 74). Представляется важным подчеркнуть и такой факт, как отсутствие сколь-нибудь ясных рациональных альтернатив государственного устроения на новом этапе. В условиях расширяющегося московского государства в умах политического класса, как уже отмечалось, господствовали понятия княжеской вотчины. Вотчинное правление не предполагает урегулирования интересов, осуществления некоторой внутренней политики, оно держалось на отношениях господства-подчинения. То есть в московском государстве XV-XVI вв. не вызрело одно из важных условий становления политики - не сложилась альтерната вотчинной модели государственного устройства. Чтобы стала формироваться политика как сфера борьбы и согласования интересов «надобно предположить целый ряд политических и юридических понятий о народе и государстве, о власти и свободе, о личных и политических правах, об общем и частном интересе, о политическом представительстве и частном полномочии» (Ключевский, 1993b). Ключевский рассуждает в данном случае о необходимых предпосылках формирования земского представительного собрания. Но эти его размышления вполне пригодны для ответа на вопрос, почему стихийный процесс становления политики в России завершился во второй половине XVI в. неудачей. Вотчинное устроение рассматривало власть как собственность. Вотчинное понимание власти усиливалось религиозным миросозерцанием, которое утверждало идею царя как проводника воли Божией, которому предоставлена безграничная власть для устроения земных дел. К перемене взглядов на государственное устройство российская вотчинная элита оказалась не готова.

B XVI-XVIII вв., политика была окончательно искоренена из общественной жизни. Были лишены своей независимости боярство и церковь, права и привилегии вольных городов стали достоянием истории. Политика исчезла. Нарождающийся диалог интересов уступил место монологу власти, ее бесконтрольности, нерегулируемости.

В отношениях государства и общества утвердился принцип самодержавного властвования с помощью бюрократии, которая была не в состоянии отражать или представлять многообразные интересы все более динамичного общества. Ключевский констатирует, что в XIX веке «Россия управлялась не аристократией и не демократией, а бюрократией, т. е. действовавшей вне общества и лишенной всякого социального облика кучей физических лиц разнообразного происхождения, объединенных только чинопроизводством» (там же: 130). 
В дальнейшей российской истории менялись формы власти: «коммунистическая» власть, «демократическая» власть - но все они относились к государству как к вотчине. Процесс принятия решений монополизировался царем-самодержцем, Компартией, Президентом. Политика как представительство интересов во власти, как широкое участие социальных сил в принятии общезначимых решений, за исключением кратковременных периодов, исключалась из общества. Политические события эпохи глобализации все более свидетельствуют о том, что общества без политики оказываются обществами без будущего. Там, где нет политики, там нет стратегической стабильности, там исчезают государства (Царская Россия, Советский Союз), там политика врывается в жизнь народов в самых радикальных и кровавых формах («оранжевые революции»).

Современная российская власть наступает на грабли, на которые уже наступала царская и советская власть. Крах социализма был вызван, прежде всего, кризисом традиционной бюрократически-властной системы управления. В течение всего двадцатого века России не удалось принципиально изменить модель управления. В конце XX века под натиском реальностей власть внесла некоторые изменения в процесс функционирования политической системы, но принципиальных изменений в процесс принятия решений не вносится. Решения принимаются по принципу исторически сложившихся бюрократически-властных процедур. В патерналистски-подданническом обществе накапливается пар, который в очередной раз непредсказуемо для общества и власти взорвет систему социальной несправедливости и коррупции.

\section{СПИСОК ЛИТЕРАТУРЫ}

Алексеев, Н. (1998) Русский народ и государство. М. : Аграф.

Валишевский, К. (1989) Иван Грозный. М. : ИКПА.

Валишевский, К. (1993) Смутное время. М. : СП «Квадрат».

Ключевский, В. О. (1993а) Русская история. Полный курс лекций : в 3 кн. М. : Мысль. Кн. 1.

Ключевский, В. О. (1993b) Русская история. Полный курс лекций : в 3 кн. М. : Мысль. Кн. 2.

Ковалевский, М. М. (1997) Из истории государственной власти в России // Антология мировой политической мысли : в 5 т. М. : Мысль. Т. 4.

Костомаров, Н. И. (1991) Русская история в жизнеописаниях ее главнейших деятелей. М. : Мысль.

Платонов, С. Ф. (1995) Очерки по истории смуты в московском государстве XVI-XVII вв. М. : Памятники исторической мысли.

Сергеев, А. Г. (1997) Правители государств и отцы церкви Европы за 2000 лет. М. : Посад.

Фёгелин, Э. (1997) Представительство и существование // Антология 
мировой политической мысли : в 5 т. М. : Мысль. Т. 2. Зарубежная политическая мысль XX в.

Примечание:

${ }^{1}$ После смерти Василия III (1533 г.) борьба за власть приобрела самые крайние формы: фаворитом Елены Глинской были убиты братья Василия III, Юрий и Андрей, как вероятные претенденты на престол; затем, в 1538 г., в результате боярского заговора была отравлена Елена, а ее фаворита, Ивана Телепова уморили голодом. Правителем России и опекуном Ивана IV стал боярин Василий Шуйский. В 1540 г. в результате очередного переворота бояре свергли семейство Шуйских и возвели в правители Ивана Бельского. В 1542 г. Иван Шуйский поднял бунт, захватил Кремль. Иван Бельский был казнен. И, наконец, подросший Иван IV велит казнить одного из Шуйских, а всех Шуйских разогнать по отдельным местам и заточить в темницы (см.: Сергеев, 1997: 408-410).

Буренко Владимир Иванович - доктор политических наук, професcop, профессор кафедры философии, политологии и культурологи Московского гуманитарного университета. Адрес: 111395, Россия, г. Москва, ул. Юности, д. 5. Тел.: +7 (499) 374-61-81. Эл. адрес: vburenko@mail.ru

Burenko Vladimir Ivanovich, Doctor of Political Science, Professor, Department of Philosophy, Culturology and Politology, Moscow University for the Humanities. Postal address: 5 Yunosti St., 111395 Moscow, Russian Federation. Tel.:+7 (499) 374-61-81. Email: vburenko@mail.ru 